УДК 338.47

DOI: https://doi.org/10.37320/2415-3583/11.8

Вікулова А.О.

кандидат економічних наук, асистент, Киівський національний університет імені Тараса Шевченка ORCID: http://orcid.org/0000-0001-8506-0966

\title{
КОНЦЕПТУАЛЬНІ ЗАСАДИ УПРАВЛІННЯ ІНТЕЛЕКТУАЛЬНОЮ ВЛАСНІСТЮ У СИСТЕМІ ТРАНСФЕРУ ТЕХНОЛОГІЙ: ДОСВІД ПІВДЕННОЇ КОРЁ̈
}

\begin{abstract}
У статті проаналізовано систему управління інтелектуальною власністю у Південній Кореї. Зокрема, проведено аналіз сучасного стану сфери інтелектуальної власності у Південній Кореї; досліджено систему наџіонального регулювання та міжнародних угод у сфері трансферу технологій Республіки Корея; ідентифіковано південнокорейську систему управління інтелектуальною власністю, шзо дало змогу визначити переваги, недоліки та сформулювати пропозииії шодо покрашення системи управління інтелектуальною власністю в Південній Кореї. Домінуючими методами дослідження є: критичний аналіз та синтез, метод узагальнення та логічні методи і метод структурованого порівняння на основі огляду літератури з інтерпретаиійним підходом. Це дослідження було проведено за допомогою конщептуального апарату дослідження, сформульовано висновки логічного узагальнення та абстрагування.
\end{abstract}

Ключові слова: інтелектуальна власність; трансфер технологій; закордонний досвід; патенти; інновації; управління інтелектуальною власністю.

Постановка проблеми. Південна Корея є яскравим прикладом економічного дива, оскільки вона $\epsilon$ «азійським тигром», тобто однією із країн Азії, що показали стрімке економічне зростання в другій половині XX століття. Всього за 50 років Південна Корея перетворилася на одну $з$ найбагатших держав світу і сьогодні $є$ шостим за величиною експортером у світі. Як і будь-яка інша країна світу, Республіка Корея перебуває під значним впливом 3 боку науково-технічного прогресу, що приводить до появи все більшої кількості об'єктів інтелектуальної власності, а також до засобів порушення прав власності на ці об'єкти. Саме тому надзвичайно важливим $є$ дослідження сфери управління інтелектуальною власністю, а також виявлення усіх переваг та недоліків цієї інституційної системи.

Аналіз останніх досліджень і публікацій. Економічний аспект інтелектуальної власності висвітлено у працях багатьох іноземних учених та практиків, серед яких виділяємо праці Г. Бромберга, Дж. Гелбрейта, В. Гойля, Г. Десмонда, Г. Іцковіца, А. Козирєва, Ю. Конова, Р. Левіна, Б. Леонтьєва, Р. Нельсона, В. Мухопада, Т. Стюарта, А. Саннікова, М. Сеннікова, Г. Чесбро, Л. Шаршукової та ін. Сучасні тенденції формування ефективної інноваційної моделі економічного розвитку та економічні проблеми управління інтелектуальною власністю відображені у дослідженнях українських учених: Г. Андрощука, Ю. Бажала, В. Базилевича, О. Бутнік-Сіверського, В. Валлє, М. Вачевського, В. Вірченка, А. Вітренка, О. Гордова, Н. Гражевської, В. Геєця, В. Дроб'язко, В. Зінова, І. Сгорова, О. Жилінської, Т. Затонацької, А. Ігнатюк, І. Корнілової, І. Одотюка, В. Семиноженка, В. Хаустова, П. Цибульова, В. Чеботарьова, Д. Черваньова,
О. Ястремської й ін. Незважаючи на значну кількість наукових праць, присвячених інтелектуальній власності, грунтовне вивчення світового досвіду управління інтелектуальною власністю у системі трансферу технологій поки що відсутнє.

Метою статті $\epsilon$ комплексний аналіз інституційного середовища Республіки Корея, а саме суб'єктів управління інтелектуальною власністю. Для досягнення поставленої мети було вирішено такі завдання: проведено аналіз сучасного стану сфери інтелектуальної власності в Південній Кореї; досліджено систему національного регулювання та міжнародних угод у сфері трансферу технологій Республіки Корея; ідентифіковано південнокорейську систему управління інтелектуальною власністю; визначено переваги, недоліки та сформульовано пропозиції щодо покращення системи управління інтелектуальною власністю у Південній Кореї.

Виклад основного матеріалу дослідження. В умовах високого рівня науково-технічного прогресу та в епоху бурхливого розвитку технологій права інтелектуальної власності є надзвичайно важливою сферою економічної діяльності. Ця теза підтверджується збільшенням кількості поданих патентних заявок у всьому світі.

Щороку, відповідно до звітів Всесвітньої організації інтелектуальної власності, Корейське відомство інтелектуальної власності займає провідні позиції у світі за кількістю поданих патентних заявок.

Щодо національного регулювання та міжнародних угод у сфері інтелектуальної власності Республіки Корея, то патенти, корисні моделі, промислові зразки, торговельні марки, а також 
авторські та суміжні права юридично визнані в Південній Кореї. У 1995 році країна покращила свої закони про права інтелектуальної власності, щоб привести їх у відповідність з Угодою Світової організації торгівлі щодо торговельних аспектів інтелектуальної власності (TRIPs). Вона продовжує оновлювати свої закони про захист прав інтелектуальної власності, щоб поширювати захист на нові галузі, такі як електронна торгівля та комерційні таємниці. Міжнародний тиск, особливо з боку США, залишається сильним, щоб запровадити додаткові заходи захисту [11].

Винаходи у Південній Кореї захищаються протягом 20 років 3 дати подання заявки відповідно до Патентного закону. Термін захисту іноді може бути продовжений на строк до п'яти років, щоб компенсувати час, необхідний для отримання нормативного дозволу на винаходи. Обов'язкове ліцензування може знадобитися для виправлення недобросовісної практики торгівлі. У сфері патентного права Республіка Корея підписала Договір про патентну кооперацію від 10 серпня 1984 року. Відповідно до чинного законодавства (включаючи Патентний акт, Закон про захист від недобросовісної конкуренції та захист комерційної таємниці) покарання за порушення прав інтелектуальної власності на патенти можуть становити 50 мільйонів вон у вигляді штрафу або п’ять років ув'язнення $[1 ; 11 ; 12]$.

Корисні моделі захищаються патентом, який застосовується до продуктів (але не до методів), які не відповідають необхідному рівню патентоспроможності. Будь-яка особа, яка подала заявку на патент, може подати заявку на корисні моделі 3 тим же предметом і претензійним пріоритетом, i навпаки. Ця система подвійного патентування забезпечує заявникам бездоганний захист. Ті самі процедури встановлення патентних прав застосовуються до корисних моделей, за винятком того, що термін захисту триває 10 років, а не 20 років $[1 ; 11]$.

Період захисту промислового дизайну становить 10 років з моменту реєстрації; однак він не може перевищувати 10 років 3 дати його першого комерційного використання або 15 років від дати його створення. Закон "Про захист прав на інтегральні мікросхеми”, прийнятий 1993 року, зробив несанкціоновану передачу інтегральних мікросхем чи їх копіювання порушеннями зареєстрованого промислового дизайну. Республіка Корея підписала Гаазьку угоду про реєстрацію промислових зразків 01.07.2014 року [11]. Комерційні таємниці отримують захист відповідно до Закону про захист недобросовісної конкуренції та комерційних таємниць, який замінив Закон про недобросовісну конкуренцію в 1999 році. Цей акт визначає комерційні таємниці як «технічну чи ділову інформацію, корисну для ведення бізнесу». Закон посилив покарання за порушників (до яких зараз входять колишні працівники, які продають комерційні секрети третім особам). Поправка до закону 2004 року передбачає охорону комерційної таємниці на рівні, подібному до Закону США про економічний шпіонаж 1996 року. Це законодавство було відповіддю на зростаючу тенденцію промислового шпигунства щодо напівпровідників, мобільних телефонів та інших високотехнологічних сфер. У переглянутому законі діяльність iз недобросовісної конкуренції визначається як «діяння, вчинене 3 метою недобросовісної конкуренції через порушення добросовісності та надійності торговельного порядку в комерційних операціях». Порушення комерційної таємниці розцінюється як кримінальне правопорушення iз застосуванням каральних заходів ув'язнення та/ або штрафів, еквівалентних 2-10-кратному розмірунедоотриманогогрошового прибутку $[1 ; 3 ; 11]$.

Одним 3 органів, що очолює систему управління інтелектуальною власністю Республіки Корея, є Міністерство економіки та знань. Воно виконує регулюючу функцію економічної політики, особливо щодо промислового й енергетичного секторів. Міністерство також працює над залученням іноземних інвестицій у Корею та націлене на створення позитивного іміджу республіки за допомогою демонстрації інноваційних і передових технологій у різних урядових проектах.

Другим органом є Міністерство культури, спорту та туризму Республіки Корея, яке є центральним державним органом, відповідальним за галузі туризму, культури, мистецтва, релігії та спорту [10].

Вищезазначеним міністерствам підпорядковуються такі органи у сфері інтелектуальної власності:

1) Корейське відомство інтелектуальної власності (КIPO), основною функцією якого є видача патентів (в т.ч. на товарні знаки), а також боротьба 3 недобросовісною конкуренцією [8]. Це відомство має у своєму підпорядкуванні:

Трибунал інтелектуальної власності, який керує апеляціями та судовими розглядами про визнання недійсними прав промислової власності;

Корейський інститут патентної інформації (KIPI), який надає інформацію про права промислової власності на створення інформаційної інфраструктури для інтелектуальної власності Кореї; підтримує впровадження сучасної системи патентного адміністрування, керує центром управління даними, центром оцифрування патентного документообігу, консультаційним центром, а також управляє інформаційною службою інтелектуальної власності в Кореї (KIPRIS) та розробляє бази даних Корейських патентних рефератів; надає послуги з розроблення патентної інформації, послуги із сертифікації комерційної таємниці та інфраструктуру патентної інформаційної служби [6]; 
Міжнародний інститут інтелектуальної власності (IIPTI), що надає освітні послуги з питань інтелектуальної власності в Кореї (проведення семінарів, курсів тощо) [2];

Корейський інститут інтелектуальної власності, метою якого $є$ покращення політики у сфері інтелектуальної власності, просування досліджень у сфері інтелектуальної власності та міжнародна кооперація [5];

Службу насінництва та сортів, що займається видачею патентів на нові сорти рослин [7];

2) Корейська комісія з авторського права, яка: врегульовує авторські спори, сприяє законному та справедливому використанню творів, проводить заходи щодо освіти та навчання з питань авторського права, проводить дослідження в цій галузі, оцінює порушення авторських прав, проводить їх реєстрацію [4];

3) Асоціація патентних повірених в Кореї (KРAА), яка проводить практичні навчання та обов'язкову підготовку патентних повірених, а також оприлюднює про них інформацію. 29.06.2011 року було підписано договір із Корейським офісом інтелектуальної власності (КIPO) 3 метою надання практичних послуг для патентних повірених, які нещодавно пройшли іспит на патентного повіреного [9].

Регіональний рівень системи управління інтелектуальною власністю представлений Групою експертів із прав інтелектуальної власності (IPEG).

Республіка Корея є членом міжнародних організацій, а також підписантом таких угод та конвенцій у цій сфері, як:

- Всесвітня організація інтелектуальної власності (BOIB);

- Паризька конвенція про захист інтелектуальної власності;

- Угода ТРІПС - Торговельні аспекти прав інтелектуальної власності (TRIPS) [1].
Особливої уваги заслуговує політика уряду Південної Кореї щодо питань інтелектуальної власності. Оскільки, за даними Корейського інституту інтелектуальної власності, 12,5\% корейських компаній малого та середнього бізнесу, а також венчурних підприємств щорічно недоотримують $12 \%$ доходів у зв'язку з незахищеністю своєї інтелектуальної власності, то ще у 2018 році було оголошено про підтримку 60 проектів, спрямованих на розповсюдження та захист інтелектуальної власності на світовому ринку та розвиток цієї сфери. Серед них:

- покращення захисту прав інтелектуальної власності за кордоном;

- інноваційний розвиток технологій компаній середнього та малого бізнесу;

- розроблення технологій промислової конвергенції;

- підтримка вітчизняних компаній у вирішенні міжнародних конфліктів, пов'язаних із правами інтелектуальної власності тощо [14].

Також агресивною та ефективною $є$ політика підтримки статусу Республіки Корея як творця об'єктів інтелектуальної власності. Так, Міністерство культури, спорту і туризму знищило 29, 1 мільйона незаконних онлайн-файлів, зменшивши ї кількість із 117,4 мільйонів файлів у 2015 році. Також знищили 7,8 мільйона копій на жорстких дисках музичних файлів, відео, публікацій, ігор та мультфільмів у 2016 році, зменшивши їх кількість iз 14,5 мільйонів у 2015 році. Міністерство також заявило, що зменшення відбулося за рахунок кращого освітнього процесу уряду Кореї щодо незаконності завантаження піратських матеріалів. Було досліджено південнокорейські університетські кампуси та конфісковано 21304 незаконно скопійованих книг, що на 30,4\% більше, ніж 16335 копій, вилучених у 2015 році. Судова поліція Міністерства провела програмне обстеження 195 компаній, які використовують спеціальне програмне забезпе-

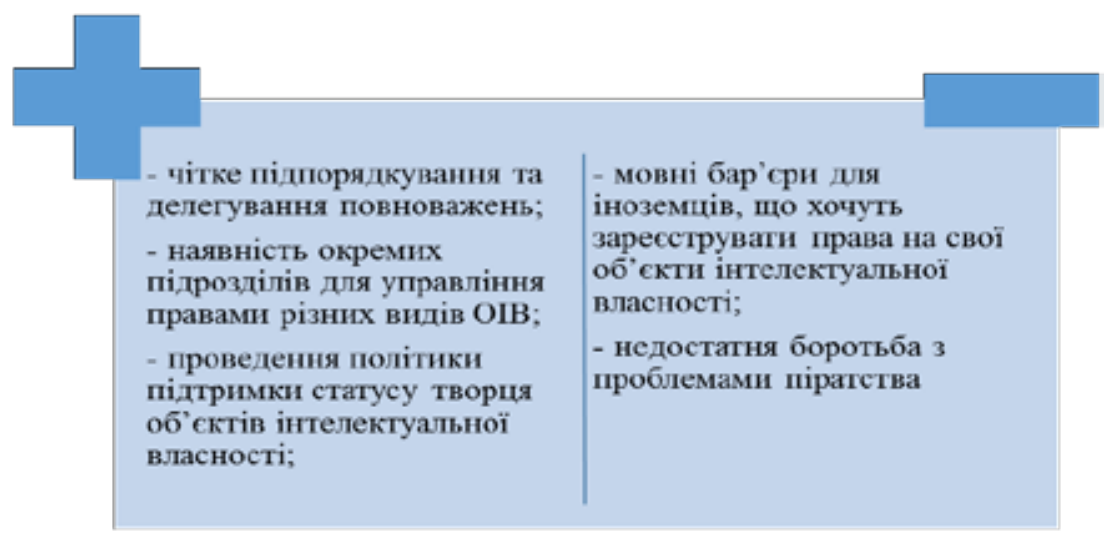

Рисунок 1 - Переваги та недоліки південнокорейської системи управління інтелектуальною власністю

Джерело: систематизовано автором 
чення для дизайну, таке як CAD та Adobe. Вона виявила 3024 випадки незаконного використання програмного забезпечення, приблизно таке ж число, як у 2015 році. Також міністерство здійснило рейдерство на 271 компанію та виявило 3050 випадків незаконного використання програмного забезпечення, а рівень піратства становив 29,6\% [3].

3 вищенаведеної інформації можна дійти висновку, що у Південній Кореї діє жорстка політика щодо сфери інтелектуальної власності, а отже, система управління нею є переважно дієвою. Окрім цього, можна виділити ще низку таких переваг, як (рис. 1):

- чітке підпорядкування та делегування повноважень;

- наявність окремих підрозділів для управління правами різних видів ОIВ;

- проведення політики підтримки статусу творця об'єктів інтелектуальної власності;

- проведення висококваліфікованої експертизи та надання консультацій.

Недоліки:

- мовні бар'єри для іноземців, що хочуть зареєструвати права на свої об'єкти інтелектуальної власності;

- недостатня боротьба з проблемами піратства.

Серед шляхів коригування недоліків варто виділити такі, як:

- проведення політики відкритості іноземним власниками OIB за рахунок проведення навчань іноземців у сфері IB та перекладу офіційних сайтів англійською мовою;

- впровадження та підтримка жорсткої політики боротьби з піратством;

- проведення підтримки розвитку сфери IB на регіональному рівні;

- підвищення конкурентоспроможності вітчизняних ОIB на міжнародних ринках;

- покращення роботи служб IB на підприємствах для збільшення ОІВ та підвищення їхньої якості.

Висновки. Загалом у світі простежується чітка тенденція збільшення кількості об'єктів інтелектуальної власності, а саме таких, що захищаються патентним законодавством. Це явище пояснюється швидкими темпами розвитку науково-технічного прогресу та інформаційних технологій. Корейське відомство інтелектуальної власності посідає четверте місце за кількістю поданих заявок на патенти у світі. Об'єктами захисту сфери інтелектуальної власності є: авторські та суміжні права, винаходи (патент), корисні моделі, промисловий дизайн, комерційна таємниця, товарні знаки та сорти рослин. За цими об'єктами Республіка Корея $є$ членом-підписантом міжнародних конвенцій, угод та договорів, серед яких: Всесвітня організація інтелектуальної власності (BOIB); Паризька конвенція про захист інтелектуальної власності та членство в угоді ТРІПС - Торговельні аспекти прав інтелектуальної власності (TRIPS). Основними органами у сфері управління IB $€$ Міністерство економіки та знань, а також Міністерство культури, спорту та туризму Республіки Корея, що мають у своєму підпорядкуванні Корейське відомство інтелектуальної власності та Корейську комісію з авторського права відповідно. Наведена система має низку переваг: чітке підпорядкування та делегування повноважень; наявність окремих підрозділів для управління правами різних видів ОІВ; проведення політики підтримки статусу творця об'єктів інтелектуальної власності; проведення висококваліфікованої експертизи та надання консультацій. Недоліками є: мовні бар'єри для іноземців, що хочуть зареєструвати права на свої об'єкти інтелектуальної власності, та недостатня боротьба з проблемами піратства. Шляхами покращення південнокорейської системи управління інтелектуальною власністю є: проведення політики відкритості іноземним власникам OIB за рахунок проведення навчань іноземців у сфері IB та перекладу офіційних сайтів англійською мовою; впровадження та підтримка жорсткої політики боротьби з піратством; проведення підтримки розвитку сфери IB на регіональному рівні; підвищення конкурентоспроможності вітчизняних ОIB на міжнародних ринках; покращення роботи служб IB на підприємствах для збільшення ОIB та підвищення їхньої якості.

\section{Список використаних джерел:}

1. Intellectual Property in South Korea. URL: https://www.wipo.int/publications/en/details.jsp?id=253\&plang=EN (дата звернення: 30.04.2020).

2. International Intellectual Property Training Institute (IIPTI). URL: http://iipti.kipo.go.kr/EN/ (дата звернення: 20.04.2020).

3. Korea-5-Protection of Property Rights. URL: https:/www.export.gov/ article?id=Korea-Protection-of-Property-Rights (дата звернення: 25.04.2020).

4. Korea Copyright Commission. URL: https://www.copyright.or.kr/eng/main. do (дата звернення: 25.04.2020).

5. Korea Institute of Intellectual Property (KIIP). URL: https://www.kiip.re.kr/en/index.do (дата звернення: 28.04.2020).

6. Korea Institute of Patent Information (KIPI). URL: http://www.kipi.or.kr/englishMain.do (дата звернення: 28.04.2020).

7. Korea Seed \& Variety Service. URL: https://www.seed.go.kr/english/index.jsp (дата звернення: 24.04.2020).

8. Korean Intellectual Property Office (KIPO). URL: https://www.kipo.go.kr/en/HtmlApp?c=97000\&catmenu=ek07_03_01 (дата звернення: 24.04.2020).

9. Korean Patent Attorneys Association (KPAA). URL: http://www.kpaa.or.kr/kpaa/eng/2-1.do?clickPage=221 (дата звернення: 24.04.2020). 
10. Ministry of Culture, Sports and Tourism. URL: http://www.mcst.go.kr/english/index.jsp (дата звернення: 04.05.2020).

11. The Economist Intelligence Unit «Protection of intellectual property in South Korea». URL: http://country.eiu.com/ article.aspx?articleid=1893487173\&Country=South\%20Korea\&topic=Regulation\&s_4 (дата звернення: 04.05.2020).

12. World Intellectual Property Organization. URL: http://www.wipo.int/portal/en/ (дата звернення: 04.05.2020).

13. Самсонова В. Г. Патентная деятельность Южной Кореи в условиях развития креативной экономики. URL : http://onekorea.ru/2015/04/18/patentnaya-deyatelnost-yuzhnoj-korei-v-usloviyax-razvitiya-kreativnoj-ekonomiki (дата звернення: 24.04.2020).

14. Южная Корея занялась проблемой интеллектуальной собственности. Окно в Корею. URL: http://k-window.com/ politics/yuzhnaya-koreya-zanyalas-problemoj-intellektualnoj-sobstvennosti/ (дата звернення: 02.05.2020).

\section{References:}

1. Intellectual Property in South Korea. URL: https://www.wipo.int/publications/en/details.jsp?id=253\&plang=EN (accessed: 30.04.2020)

2. International Intellectual Property Training Institute (IIPTI). URL: http://iipti.kipo.go.kr/EN/ (accessed: 20.04.2020).

3. Korea-5-Protection of Property Rights. URL: https://www.export.gov/ article?id=Korea-Protection-of-Property-Rights (accessed: 25.04.2020).

4. Korea Copyright Commission. URL: https://www.copyright.or.kr/eng/main.do (accessed: 25.04.2020).

5. Korea Institute of Intellectual Property (KIIP). URL: https://www.kiip.re.kr/en/index.do (accessed: 28.04.2020).

6. Korea Institute of Patent Information (KIPI). URL: http://www.kipi.or.kr/englishMain.do (accessed: 28.04.2020).

7. Korea Seed \& Variety Service. URL: https://www.seed.go.kr/english/index.jsp (accessed: 24.04.2020).

8. Korean Intellectual Property Office (KIPO). URL: https://www.kipo.go.kr/en/HtmlApp?c=97000\&catmenu=ek07_03_01 (accessed: 24.04.2020).

9. Korean Patent Attorneys Association (KPAA). URL: http://www.kpaa.or.kr/kpaa/eng/2-1.do?clickPage=221 (accessed: 24.04.2020).

10. Ministry of Culture, Sports and Tourism. URL: http://www.mcst.go.kr/english/index.jsp (accessed: 04.05.2020).

11. The Economist Intelligence Unit «Protection of intellectual property in South Korea». URL: http://country.eiu.com/ article.aspx articleid=1893487173\&Country $=$ South\%20Korea\&topic=Regulation\&s_4 (accessed: 04.05.2020).

12. World Intellectual Property Organization. URL: http://www.wipo.int/portal/en/ (accessed: 04.05.2020).

13. Samsonova V. G. Patentnaya deyatel`nost' Yuzhnoj Korey`v uslovy`yax razvy`ty`ya kreaty`vnoj ekonomy`ky`. URL : http://onekorea.ru/2015/04/18/patentnaya-deyatelnost-yuzhnoj-korei-v-usloviyax-razvitiya-kreativnoj-ekonomiki (accessed: 24.04.2020).

14. Yuzhnaya Koreya zanyalas` problemoj y`ntellektual`noj sobstvennosty`. Okno v Koreyu. URL: http://k-window.com/ politics/yuzhnaya-koreya-zanyalas-problemoj-intellektualnoj-sobstvennosti/ (accessed: 02.05.2020).

Vikulova Alona

Taras Shevchenko National University of Kyiv

\section{CONCEPTUAL PRINCIPLES OF INTELLECTUAL PROPERTY MANAGEMENT IN THE TECHNOLOGY TRANSFER SYSTEM: THE EXPERIENCE OF SOUTH KOREA}

This paper outlines a comprehensive study of the management of intellectual property in the context of transfer technology in Korea Republic. The following tasks were set as the article's objectives: 1) analysis of the current state of intellectual property in South Korea; 2) study of the system of national regulation and international agreements in the field of technology transfer of the Republic of Korea; 3) identification of the South Korean system of intellectual property management; 4) identification of advantages, disadvantages and formulation of a proposal to improve the intellectual property management system in South Korea.

The dominant research methods are: the critical analysis and synthesis, the generalization method and the logical methods, and the method of structured comparison based on the literature review with the interpretative approach. The literature review was conducted based on primary sources. It was also done on queries into journal databases such as SCOPUS and the Web of Science. This study was carried out through the conceptual apparatus of investigation and formulated conclusions of logical generalization and abstraction. The results of the study were visualized through a graphicalmethod.Ittakes into account the multidimensionality of the analysis, the theoretical andempiricalunityprinciple.

The paper dealing with transfer of technology and intellectual property: lessons from Korea's experience in the context of debate on the impact and relevance of intellectual property to development. It confirms, in essence, the finding of recent studies, according to which the effects of intellectual property on technology transfer will vary depending on countries' levels of economic development. The protection of intellectual property rights has increasingly become an important issue in multilateral trade negotiations. This study summarizes a case study conducted by the author based on a long period of research on technology transfer and local capacity building in that country. This paper analyzed Korea's experience of rapid industrialization over the relevance of intellectual property in this process. This study found that there are quite different trends in the selection of the legal means of protection; firms in the software industry prefer to copyrighting, whereas firms in the manufacturing industry prefer to patent.

Key words: intellectual property; technology transfer; foreign experience; patents; innovations; intellectual property management.

JEL classification: A13, O10. 